\title{
Mammalian target of rapamycin and head and neck squamous cell carcinoma
}

\author{
Yu-Min Liao ${ }^{1}$, Charles Kim² and Yun Yen ${ }^{2 *}$
}

\begin{abstract}
Head and neck squamous cell carcinoma (HNSCC), a significant cause of cancer deaths worldwide, has multiple stepwise malignant evolutions. Mammalian target of rapamycin (mTOR) plays a critical role in tumor development, invasion, metastasis and angiogenesis that impact local recurrence and survival. mTOR can also act as a biomarker for personalized adjuvant therapy. In in vivo and in vitro studies, mTOR inhibitor suppresses tumor growth and sensitizes HNSCC to radiation, cytotoxic agents and epidermoid growth factor receptor inhibitors. We have reviewed the pathogenesis of HNSCC, mTOR pathway, mTOR inhibitor and the role of mTOR in HNSCC.
\end{abstract}

\section{Review}

Head and neck squamous cell carcinoma (HNSCC) is the sixth most common cancer worldwide and accounts for approximately 650,000 new diagnoses and 350,000 cancer deaths every year [1]. Smoking and alcohol are the most well known carcinogens of HNSCC [2]. In some areas of Asia, chewing betel quid, a psychoactive substance that always contains areca nut, betel leaf and calcium hydroxide, is a distinct risk factor that exerts a synergistic effect with smoking and alcohol consumption for oral and laryngeal cancer $[3,4]$. In addition, the continuation of smoking and alcohol consumption after initial diagnosis of HNSCC increases the risk for secondary primary cancer [5]. Human papillomavirus (HPV), predominantly type 16 , infection inducing genomic instability is another mechanism for tumorigenesis in the oropharynx that is distinct from the role of smoking or alcohol [6].

Surgery and radiotherapy are the main modality of HNSCC treatment [7]. Chemotherapy, acting as a radiosensitizer, increases survival in locally advanced disease $[8,9]$. To treat early disease, surgery is preferred. Radiotherapy is an alterative method for organ preservation for laryngeal cancer $[10,11]$. In unresectable settings, concurrent cisplatin chemoradiotherapy that provides better disease free survival and overall survival than radiotherapy alone is the standard of care [9]. Surgery-

\footnotetext{
* Correspondence: YYen@coh.org

2Department of Molecular Pharmacology, Beckman Research Institute, City of Hope Comprehensive Cancer, Duarte, CA 91010, USA

Full list of author information is available at the end of the article
}

treated, advanced patients with high risk factors can also obtain benefit of local and regional control and progression free survival by adding concurrent chemotherapy to postoperative radiotherapy [12]. Overall, the incorporation of concurrent chemoradiotherapy to management of HNSCC absolutely increases survival rate by $6.5 \%$ at year-five [13]. Recently, cetuximab, an epidermal growth factor receptor-specific monoclonal antibody, plus radiation were shown to improve survival rate as compared to radiation treatment alone [14]. However, a retrospect study suggests the duration of progression free survival and overall survival is shorter in patient receiving cetuximab plus radiation than those with cisplatin plus radiation [13]. Multi-modality treatment or targeted therapy containing management does not significantly improve overall survival.

HNSCC has a complex mechanism of carcinogenesis that involves multiple genetic abnormalities, stepwise evolution and signaling pathway alternation [7,15-18]. Alternations of p53, p16 and cyclin D1 (CCND1) result in limitless growth of tumor cells [4,19-22]. Change of epidermal growth factor receptor (EGFR), c-MET, phosphatidylinositol 3-kinase, catalytic, alpha polypeptide (PIK3CA), Ras-mitogen-activate protein kinase (RasMAPK), phosphatase and tensin homolog (PTEN) and transforming growth factor-beta (TGF-beta) are essential to affect growth factor signaling that impact cell proliferation, apoptosis and survival [23-28]. High expression of nuclear factor Kappa B (NF-Kappa B), surviving and B cell lymphoma $-2(\mathrm{Bcl}-2)$ are positively associated with poor survival [29-31]. 


\section{Target of rapamycin (TOR) pathway}

Mammalian TOR (mTOR), a protein kinase encoded by FK506 binding protein 12-rapamycin associated protein 1 (FRAP1) gene [32]., is an important downstream target signal of PI3K pathway. (Figure 1) [33]. The protein contains an 12-kDa FK506-binding protein (FKBP12), rapamycin binding domain, Huntington Elongation Factor 3 PR65/ATOR (HEAT) motifs, FK506 binding protein 12-rapamycin associated protein (FRAP1)-ataxia telangiectasia mutated (ATM)-transformation transcription domain-associated protein (FAT) and FAT C terminus (FATC) domain. In terms of structure and function, mTOR consists of two distinct complexes: mTOR complex 1 (mTORC1) and mTOR complex 2 (mTORC2) [34,35]. mTOR, regulatory-associated protein of mTOR (Raptor) and G-protein-subunit-like protein form mTORC1, a nutrition-sensitive complex. mTORC1 is

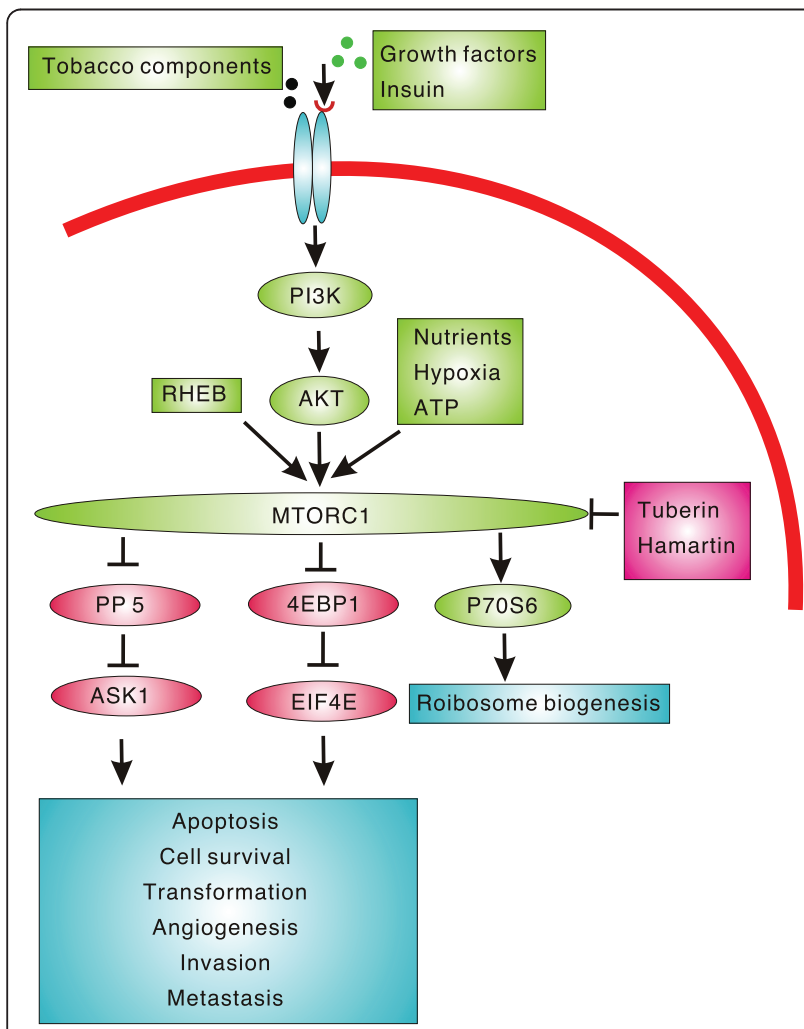

Figure 1 Mammalian target of rapamycin is a key regulator in development and progression of cancer. Mammalian target of rapamycin responds to stimuli of growth factor, insulin, tobacco components, nutrients, hypoxia, ATP and RHEB to activate P70S6 and inhibit 4EBP1 and PP5 with subsequent dysregulation of apoptosis, cell survival, cell transformation, tumorigenesis, angiogenesis, invasion and metastasis. PI3K, phosphatidylinositol 3kinase; ATP, adenosine triphosphate; RHEB, ras homologue enriched in brain; mTORC1, mammalian target of rapamycin complex 1; PP5, protein phosphatase 5; ASK1, apoptosis-signal-regulating kinase 1; p70S6, ribosomal p70 S6; EIF4E, eukaryotic translation initiation factor 4E; 4E-BP1, EIF4E-binding protein 1. sensitive to rapamycin, control cell growth and is a key factor of the mTOR pathway [34-38]. mTORC2, a complex containing mTOR, G-protein-subunit-like protein and $\mathrm{mAVO} 3$, regulates the actin cytoskeleton and is insensitive to rapamycin [39]. As an important target kinase of the PI3K pathway, mTOR responds to multiple stimuli including: nutrients, insulin, oxygen, growth factor, ATP, Ras homologue enriched in brain (RHEB) and tobacco components [33,38,40-44]. However, mTOR is negatively regulated by complex of tuberin and hamartin [45]. Through the activation of two downstream targets p70S6K and 4EBP1, mTOR functions on translation, cell growth, protein synthesis, cell size and angiogenesis [46-48]. Activated p70S6K stimulates 5-terminal oligopyrimidine ( 5 'TOG) translation to regulate ribosome biogenesis [49]. Phosphorylated 4EBP1 disassociates with eIF4E. The free eIF4E, an oncoprotein, promotes cap-dependent translation with subsequent regulation of c-myc, cyclin D1, ornithinedecarboxylase, basic fibroblast growth factor (b-FGF), vascular endothelial growth factor (VEGF) and matrix metalloproteinase-9 (MMP-9) to affect cell survival, tumorigenesis and transformation, angiogenesis, invasion and metastasis [41,50-54]. In addition, mTOR-enhanced expression of HIF-1a protein, HIF-1 transcriptional activity, and VEGF protein are the key regulators in angiogenesis [55]. Apoptosis signalregulating kinase 1 (ASK1)-modulated apoptosis can be inhibited by mTOR-induced overexpression of protein phosphatase 5 (PP5) [56].

\section{mTOR inhibitor}

Many compounds, including rapamycin, rapalog and adenosine-5'-triphosphate (ATP)-competitive inhibitor, have been shown to block the activation of the mTOR pathway [57]. Rapamycin, an antifungal agent, [58]. binds to the FKBP12-rapamycin (FRB) domain of mTORC1 to interrupt downstream activation [59]. Poor water solubility, absorption, limited bio-availability, hepatic first-pass effect and drug interaction account for interpatient variability that requires therapeutic drug monitoring for the complex pharmacokinetic behaviors [60]. Although rapamycin is a promisingly cytostatic anticancer agent in the National Cancer Institute's screening program, [35]. those pharmacologic characteristics limit the practical application $[61,62]$. In order to improve the pharmacokinetic features of rapamycin, a chemical modification at C-40-0 can develop three new rapalogs including everolimus, temsirolimus and ridaforolimus that share the same mechanisms of action. They not only exert anti-cancer activity but also act as a sensitizer to radiotherapy and chemotherapy. Frequent adverse events such as fatigue, mucositis, rash, anorexia, diarrhea, nausea, thrombocytopenia, leucopenia, anemia, hyperglycemia, hyperlipidemia and hypercholesterolemia 
are limited and manageable [63]. Everolimus (RAD001) is an oral rapalog, and has better oral absorption and bioavailability profiles than compared to those of rapamycin [64,65]. It also shows sustained inhibition of S6K1 activity at the dose of $\geq 20 \mathrm{mg}$ weekly and $\geq 5 \mathrm{mg}$ daily [66]. Temsirolimus is a prodrug converted into rapamycin after intravenous infusion. It exerts evidence of activity over a dose range between 15 and $300 \mathrm{mg} /$ $\mathrm{m}^{2}$, and has the dose-limiting toxicity from thrombocytopenia [67]. Ridaforolimus is a non-prodrug rapalog, and has dose limiting toxicity from mouth sore at 28 $\mathrm{mg} / \mathrm{d}$ and maximal tolerable dose of $18.5 \mathrm{mg} / \mathrm{d}$ [68]. In a study of skin biopsy specimens, ridaforolimus significantly suppressed the expression of 4EBP1, S6 and extracellular signal-regulated kinase (ERK) [69].

\section{mTOR pathway and HNSCC}

HNSCC amplifies eukaryotic translation initiation factor $4 \mathrm{E}(\mathrm{eIF} 4 \mathrm{E})$ gene and overexpresses eIF4E protein [70]. The tumor itself, the surgical margins, and even the histologically normal epithelium in the margins were all shown to overexpress eIF4E. The strong association of elevated activity of eIF4E with high expression of mTOR downstream signals transduction (phospho-4E binding protein 1, S6, phospho-mTOR) and elevated level of AKT expression suggests the activation of AKT/mTOR pathway in the margin. High expression of phosphoP70S6 and AKT in the margin indicates that the activity of $\mathrm{AKT} / \mathrm{mTOR}$ cascade is higher in tumor margin than in the tumor itself [71]. There is a significant correlation between degree of expression of eIF4E in the margin and grading of the dysplasia $(P=.006)$ [72]. eIF4E is essential in the malignant progression of HNSCC [70]. Interestingly, higher activity of eIF4E in the tumor margin, even those free of microscopic tumor, is an independent predictor of local recurrence while histological grading of dysplasia failed to predict prognosis [73]. Nathan et al examined tumor samples from 65 patients. All biopsies expressed elevated levels of eIF4E. The intra-tumor activity of eIF4E was not different between the eIF4E-positive and -negative margin groups. Thirtysix patients (55\%) with microscopic tumor-free margins had eIF4E expression in the basal cell layer of the margin. After a median follow-up of 17 months, local-regional recurrence developed in 20 patients (56\%) with eIF4E-positive margins. In contrast, two patients (6.9\%) with absence of eIF4F expression had local recurrence after median follow-up of 14.5 months. Histologically tumor-free margin with high expression of eIF4E has a seven-fold risk of local failure. The median disease free duration is significantly shorter in the eIF4E positive margin group (eIF4E positive versus negative, 11 months versus 14 months; log-rank test, $P=.0001$ ). The prediction of recurrence by expression of eIF4E in HNSCC margin is independent from tumor size, nodal status, stage, histologic grade, tumor site, eIF4E levels in the tumor, and with the degree of dysplasia in the margins [72]. Also, the level of p-S6 expression significantly increases with the malignant progression of the tumor [74]. In addition, irradiation, an important treatment of HNSCC, promotes the expression of mTOR and AKT in HNSCC cells [75]. High expression of AKT sensitizes mTOR inhibition through down-regulation of cyclin D1 and c-myc [76,77]. Activation of AKT/mTOR pathway plays a key role in tumorigenesis and survival rate of HNSCC patients [71]. The eIF4E is a potential maker to define the molecular-free surgical margin, and is a promising predictor of survival $[72,73]$.

\section{mTOR inhibitor and HNSCC}

Temsirolimus blocks the activation of mTOR pathway in HNSCC cell line to reduce the expression of S6 and 4EBP1 with subsequently suppressed expression of FGF and VEGF that inhibited cell growth in vitro. In a xenograft study, the 4EBP1 activity of tumor cells and peripheral blood mononuclear cells (PBMC) is also reduced by mTOR inhibition $[78,79]$. Rapamycin treatment increased nuclei apoptosis in tumor in situ TUNEL assay, and reduced neovascularization [74]. To mimic patients with histologically tumor-free margin with high expression of eIF4E, the tumor cells in the culture medium were introduced into the dorsal flap of nude mice with pipettes to establish a minimal residual disease model (MRD). Measuring the tumor formation at day 21 after xenograft, the treatment group had a significantly longer median tumor free duration (treatment versus control group, 18 days versus 7 days; $P<0.0001$ ). The tumor size of treatment group was significantly smaller than those of the control group $(P<0.0001)$. In the "survival study" mTOR inhibition delayed the time to develop tumors with the volumes of at least $200 \mathrm{~m}^{3}$ in the MRD model $(P<0.0001)$. Twenty-one percent of the treated mice were free of tumors 30 days after the discontinuation of the treatment. As expected, temsirolimus treatment significantly reduced photon emission on bioluminescence imaging. The reduction increased with the continuation of the treatment. The result of the MRD model suggests that the prolonged mTOR inhibition may have clinical benefits in the adjuvant setting for patients with eIF4E positive margin [78]. mTOR inhibitor is a potential agent in HNSCC treatment. Phosphorylated mTOR, eIF4E, and high expression of AKT may be potentional biomarkers in order to select the candidate HNSCC patients for mTOR inhibitorbased adjuvant therapy $[71,77,80]$.

Everolimus enhances DNA-damage agent-induced apoptosis in tumor cells. It overcomes cisplatin resistance in small cell and non-small cell lung cancer cell 
lines, [81,82]. and sensitizes cancer cells to radiation by arresting cells in G2M phase $[79,83,84]$. In an in vivo study, temsirolimus was shown to block signal transduction of mTOR pathway to decrease VEGF production, but failed to sensitize HNSCC to radiation by clonogenic assay. In a study with cisplatin-sensitive $\mathrm{Fa}-\mathrm{Du}$ and cisplatin-resistant SCC-40 xerografts receiving 3week treatment with temsirolimus or cisplatin plus radiation, temsirolimus alone treatment, even at low doses, significantly blocked the tumor growth in both xenografts. The combination of temsirolimus with radiation (XRT) more significantly promoted radiationinduced tumor reduction $(P<0.05$; temsirolimus plus $\mathrm{XRT}$ versus. temsirolimus or XRT alone) than compared to the combination of cisplaint with XRT alone in both cisplaitn- sensitive and resistant cell lines $(P<0.05)$. Addition of cisplatin to the temsirolimus and XRT treatment failed to increase the therapeutic effect. The sensitization effect by temsirolimus is evidenced by the following: the reduced phosphorylation of 4EBP1, S6 and Bad; the increased number of radiation-related poly (ADP-ribose) polymerases (PARPs) cleavage; the increased rate of nuclei apoptosis; and the reduction of tumor vascularity by diminishing VEGF production. The median survival time was 49 days for the temsirolimus plus XRT treatment group, 38 days for the cisplatin plus XRT treatment group and 27 days for the control group for the SCC-40 cell lines. Treatment with temsirolimus alone or with the combination of XRT can significantly increase the survival rate of SCC-40 xenograft as compared to the control group $(P<0.05)$. mTOR inhibitor is a promising radio-sensitizer in HNSCC treatment [75]. Although EGFR is an important target of therapy, [85]. HNSCC poorly responds to or is refractory to antiEGFR treatment. In HNSCC cell lines Detroit 562, erlotinib blocks the activation of MAPK and suppresses the expression of AKT and p70. Temsirolimus alone failed to affect AKT and MAPK. The MAPK was completely blocked by the combination treatment while the activity of AKT was significantly inhibited. In an in vivo study, the combination therapy, erlotinib alone therapy, and the temsirolimus alone therapy obtained growth rates that was $18 \%, 34 \%$ and $13 \%$ of the rate of growth of the control group, respectively. Seven days after the treatment, the expression of pMAPK, Ki-67 and phosphop70 were significantly reduced. mTOR inhibition suppressed tumor growth of EGFR-resistant cell lines and exerted an additive effect with the combination of the EGFR inhibitor [86].

7Few HNSCC patients were enrolled into a phase 1 study to investigate the safety of an mTOR inhibitor based combination therapy. A patient with HNSCC T4N3M1 with lung metastasis with failed responses to docetaxel, cisplatin and zalutumumab partially responded to temsirolimus and metformine [87]. One oropharyngeal cancer patient obtained stable disease

Table 1 Clinical study for mTOR inhibitor in treatment of HNSCC

\begin{tabular}{|c|c|c|c|c|}
\hline Drug & $\begin{array}{l}\text { Study } \\
\text { phase }\end{array}$ & Treatment design & Disease status & $\begin{array}{l}\text { Clinicaltrial.gov } \\
\text { identifier }\end{array}$ \\
\hline Rapamycin & $|/| \mid$ & $\begin{array}{l}\text { Neoadjuvant with 21-day rapamycin followed by } \\
\text { surgery }\end{array}$ & Stage III or IVA, resectable & NCT01195922 \\
\hline \multirow[t]{5}{*}{ Temsirolimus } & $\|$ & Temsirolimus with or without cetuximab & Recurrent or metastasis & NCT01256385 \\
\hline & $\|$ & Temsirolimus alone & Recurrent or metastasis & NCT01172769 \\
\hline & $|/| \mid$ & Temsirolimus + Weekly paclitaxel + carboplatin & Recurrent or metastasis & NCT01016769 \\
\hline & $1 / 11$ & Temsirolimus, cisplatin, and cetuximab & Recurrent or metastasis & NCT01015664 \\
\hline & $\|$ & Temsirolimus and erlotinib & $\begin{array}{l}\text { Platinum-refractory or -ineligible, advanced } \\
\text { disease }\end{array}$ & NCT01009203 \\
\hline \multirow[t]{10}{*}{ Everolimus } & I & Everolimus, weekly cisplatin and XRT & Locally advanced & NCT01058408 \\
\hline & 1 & Induction with everolimus, docetaxel, and cisplatin & Locally advanced & NCT00935961 \\
\hline & I & Everolimus, weekly cisplatin and XRT & Locally advanced & NCT00858663 \\
\hline & I & Everolimus, cisplatin and XRT & Locally advanced & NCT01057277 \\
\hline & $|/| \mid$ & Induction everolimus paclitaxel, and cisplatin & Locally advanced & NCT01133678 \\
\hline & $\begin{array}{l}\text { II, } \\
\text { randomized }\end{array}$ & Adjuvant everolimus Vs placebo & $\begin{array}{l}\text { Locally advanced disease after definite local } \\
\text { treatment }\end{array}$ & NCT01111058 \\
\hline & I/IIB & Everolimus, carboplatin, and cetuximab & Recurrent or metastaasis & NCT01283334 \\
\hline & $1 / 11$ & Everolimus, cetuximab and cisplatin & Recurrent or metastaasis & NCT01009346 \\
\hline & $\|$ & Everolimus & Refractory, recurrent or metastasis & NCT01051791 \\
\hline & $\|$ & Everolimus, erlotinib & Recurrent & NCT00942734 \\
\hline Ridaforolimus & I & Ridaforolimus, cetuximab & Advanced & NCT01212627 \\
\hline
\end{tabular}


after more than 6 cycles of treatments with everolimus and weekly cisplatin. No change of expression of p21, p53 or p-AKT was found on a biopsy specimen from pretreatment and day 21 on treatment [88].

Many studies have been initiated to elucidate the role of mTOR inhibitor in the treatment of HNSCC (Table 1). National Institutes of Dental and Craniofacial Research initiated a pilot study to investigate the efficacy and molecular change of neoadjuvant 3-week treatment of rapamycin in resectable HNSCC patients. Molecular study of the specimens obtained from tumor biopsies during the period of treatment provides further information for clinical response to rapamycin (clinicaltrial.gov identifier: NCT01195922). One future randamized phase II trial of everolimus versus placebo as an adjuvant therapy in patients with locally advanced HNSCC (NCT01111058) will evaluate the benefit of long-term mTOR inhibition in patients with eIF4E positive margin [78]. Some trials will test the safety at different dosages and determine the optimal dose of mTOR inhibitor in combination with radiation or cytotoxic agents.

\section{Conclusion}

mTOR plays an important role in the complex carcinogenesis of HNSCC, predicts survival, and may be a potential biomaker to identify candidate patients for mTOR inhibition-based adjuvant therapy. Many preclinical experements suggest that the mTOR blockade has anti-tumor activity, displays radio- or chemo-sensitization, and overcomes the EGFR resistance. Further clinical trial results may provide more information about the role of $\mathrm{mTOR}$ in future studies and management of HNSCC.

\section{Author details \\ ${ }^{1}$ Division of Hematology and Oncology, Department of Internal Medicine, China Medical University Hospital, Taichung, 404, Taiwan. ${ }^{2}$ Department of Molecular Pharmacology, Beckman Research Institute, City of Hope Comprehensive Cancer, Duarte, CA 91010, USA.}

\section{Authors' contributions}

YY designed the paper. YY, YML and CK wrote the paper. All authors read and approved the final manuscript.

\section{Competing interests}

The authors declare that they have no competing interests.

Received: 6 March 2011 Accepted: 24 April 2011

Published: 24 April 2011

\section{References}

1. Parkin DM, Bray F, Ferlay J, Pisani P: Global cancer statistics, 2002. CA Cancer J Clin 2005, 55:74-108

2. Vineis P, Alavanja M, Buffler P, Fontham E, Franceschi S, Gao YT, Gupta PC, Hackshaw A, Matos E, Samet J, et al: Tobacco and cancer: recent epidemiological evidence. J Natl Cancer Inst 2004, 96:99-106.

3. Wen CP, Tsai MK, Chung WS, Hsu HL, Chang YC, Chan HT, Chiang PH, Cheng TY, Tsai SP: Cancer risks from betel quid chewing beyond oral cancer: a multiple-site carcinogen when acting with smoking. Cancer Causes Control 2010, 21:1427-1435.

4. Mack TM: The new pan-asian paan problem. The Lancet 2001, 357:1638-1639.

5. Do KA, Johnson MM, Doherty DA, Lee JJ, Wu XF, Dong Q, Hong WK, Khuri FR, Fu KK, Spitz MR: Second primary tumors in patients with upper aerodigestive tract cancers: joint effects of smoking and alcohol (United States). Cancer Causes Control 2003, 14:131-138.

6. D'Souza G, Kreimer AR, Viscidi R, Pawlita M, Fakhry C, Koch WM, Westra WH, Gillison ML: Case-Control Study of Human Papillomavirus and Oropharyngeal Cancer. New England Journal of Medicine 2007, 356:1944-1956.

7. Haddad RI, Shin DM: Recent advances in head and neck cancer. N Engl J Med 2008, 359:1143-1154.

8. Cohen EE, Lingen MW, Vokes EE: The expanding role of systemic therapy in head and neck cancer. J Clin Oncol 2004, 22:1743-1752.

9. Adelstein DJ, Li Y, Adams GL, Wagner H Jr, Kish JA, Ensley JF, Schuller DE, Forastiere AA: An intergroup phase III comparison of standard radiation therapy and two schedules of concurrent chemoradiotherapy in patients with unresectable squamous cell head and neck cancer. J Clin Oncol 2003, 21:92-98.

10. Argiris A, Karamouzis MV, Raben D, Ferris RL: Head and neck cancer. The Lancet 2008, 371:1695-1709.

11. Jones AS, Fish B, Fenton JE, Husband DJ: The treatment of early laryngeal cancers (T1-T2 N0): surgery or irradiation? Head \& Neck 2004, 26:127-135.

12. Bernier J, Domenge C, Ozsahin M, Matuszewska K, Lefebvre JL, Greiner RH, Giralt J, Maingon P, Rolland F, Bolla M, et al: Postoperative irradiation with or without concomitant chemotherapy for locally advanced head and neck cancer. N Engl J Med 2004, 350:1945-1952.

13. Pignon JP, le Maitre A, Maillard E, Bourhis J: Meta-analysis of chemotherapy in head and neck cancer (MACH-NC): an update on 93 randomised trials and 17,346 patients. Radiother Oncol 2009, 92:4-14.

14. Bonner JA, Harari PM, Giralt J, Azarnia N, Shin DM, Cohen RB, Jones CU, Sur R, Raben D, Jassem J, et al: Radiotherapy plus cetuximab for squamous-cell carcinoma of the head and neck. N Engl J Med 2006, 354:567-578

15. Wang X, Fan M, Chen X, Wang S, Alsharif MJ, Wang L, Liu L, Deng H: Intratumor genomic heterogeneity correlates with histological grade of advanced oral squamous cell carcinoma. Oral Oncol 2006, 42:740-744.

16. Leemans $C R$, Braakhuis BJ, Brakenhoff $\mathrm{RH}$ : The molecular biology of head and neck cancer. Nat Rev Cancer 2011, 11:9-22.

17. Hanahan D, Weinberg RA: The hallmarks of cancer. Cell 2000, 100:57-70.

18. Matta A, Ralhan R: Overview of current and future biologically based targeted therapies in head and neck squamous cell carcinoma. Head Neck Oncol 2009 , 1:6.

19. Somers KD, Merrick MA, Lopez ME, Incognito LS, Schechter GL, Casey G: Frequent p53 Mutations in Head and Neck Cancer. Cancer Research 1992, 52:5997-6000

20. Boyle JO, Hakim J, Koch W, van der Riet P, Hruban RH, Roa RA, Correo R, Eby YJ, Ruppert JM, Sidransky D: The incidence of p53 mutations increases with progression of head and neck cancer. Cancer Res 1993, 53:4477-4480.

21. Callender T, El-Naggar AK, Lee MS, Frankenthaler R, Luna MA, Batsakis JG: PRAD-1 (CCND1)/cyclin D1 oncogene amplification in primary head and neck squamous cell carcinoma. Cancer 1994, 74:152-158.

22. Zhang SY, Klein-Szanto AJ, Sauter ER, Shafarenko M, Mitsunaga S, Nobori T, Carson DA, Ridge JA, Goodrow TL: Higher frequency of alterations in the p16/CDKN2 gene in squamous cell carcinoma cell lines than in primary tumors of the head and neck. Cancer Res 1994, 54:5050-5053.

23. Grandis JR, Tweardy DJ: Elevated Levels of Transforming Growth Factor a and Epidermal Growth Factor Receptor Messenger RNA Are Early Markers of Carcinogenesis in Head and Neck Cancer. Cancer Research 1993, 53:3579-3584.

24. Marshall DD, Kornberg LJ: Overexpression of scatter factor and its receptor (c-met) in oral squamous cell carcinoma. Laryngoscope 1998, 108:1413-1417.

25. Kozaki K, Imoto I, Pimkhaokham A, Hasegawa S, Tsuda H, Omura K, Inazawa J: PIK3CA mutation is an oncogenic aberration at advanced stages of oral squamous cell carcinoma. Cancer Sci 2006, 97:1351-1358.

26. Qiu W, Schönleben F, Li X, Ho DJ, Close LG, Manolidis S, Bennett BP, Su GH: PIK3CA Mutations in Head and Neck Squamous Cell Carcinoma. Clinical Cancer Research 2006, 12:1441-1446. 
27. Okami K, Wu L, Riggins G, Cairns P, Goggins M, Evron E, Halachmi N, Ahrendt SA, Reed AL, Hilgers W, et al: Analysis of PTEN/MMAC1 Alterations in Aerodigestive Tract Tumors. Cancer Research 1998, 58:509-511.

28. Wang D, Song H, Evans JA, Lang JC, Schuller DE, Weghorst CM: Mutation and downregulation of the transforming growth factor beta type ॥ receptor gene in primary squamous cell carcinomas of the head and neck. Carcinogenesis 1997, 18:2285-2290.

29. Duffey DC, Chen Z, Dong G, Ondrey FG, Wolf JS, Brown K, Siebenlist U, Van Waes C: Expression of a Dominant-Negative Mutant Inhibitor $\mathrm{kBa} \pm$ of Nuclear Factor-kB in Human Head and Neck Squamous Cell Carcinoma Inhibits Survival, Proinflammatory Cytokine Expression, and Tumor Growth in Vivo. Cancer Research 1999, 59:3468-3474

30. Lin C-Y, Hung H-C, Kuo R-C, Chiang C-P, Kuo MY-P: Survivin expression predicts poorer prognosis in patients with areca quid chewing-related oral squamous cell carcinoma in Taiwan. Oral Oncology 2005, 41:645-654.

31. Gallo O, Boddi V, Calzolari A, Simonetti L, Trovati M, Bianchi S: bcl-2 protein expression correlates with recurrence and survival in early stage head and neck cancer treated by radiotherapy. Clin Cancer Res 1996, 2:261-267.

32. Moore PA, Rosen CA, Carter KC: Assignment of the Human FKBP12Rapamycin-Associated Protein (FRAP) Gene to Chromosome 1p36 by Fluorescencein SituHybridization. Genomics 1996, 33:331-332.

33. Scott PH, Brunn GJ, Kohn AD, Roth RA, Lawrence JC: Evidence of insulinstimulated phosphorylation and activation of the mammalian target of rapamycin mediated by a protein kinase B signaling pathway. Proceedings of the National Academy of Sciences of the United States of America 1998, 95:7772-7777.

34. Loewith $R$, Jacinto E, Wullschleger S, Lorberg A, Crespo JL, Bonenfant D, Oppliger W, Jenoe P, Hall MN: Two TOR Complexes, Only One of which Is Rapamycin Sensitive, Have Distinct Roles in Cell Growth Control. Molecular Cell 2002, 10:457-468.

35. Bjornsti MA, Houghton PJ: The TOR pathway: a target for cancer therapy. Nat Rev Cancer 2004, 4:335-348.

36. Hara K, Maruki Y, Long X, Yoshino K-i, Oshiro N, Hidayat S, Tokunaga C, Avruch J, Yonezawa K: Raptor, a Binding Partner of Target of Rapamycin (TOR), Mediates TOR Action. Cell 2002, 110:177-189.

37. Kim D-H, Sarbassov DD, Ali SM, Latek RR, Guntur KVP, ErdjumentBromage H, Tempst P, Sabatini DM: G[beta]L, a Positive Regulator of the Rapamycin-Sensitive Pathway Required for the Nutrient-Sensitive Interaction between Raptor and mTOR. Molecular Cell 2003, 11:895-904.

38. Kim DH, Sarbassov DD, Ali SM, King JE, Latek RR, Erdjument-Bromage $H$, Tempst P, Sabatini DM: mTOR interacts with raptor to form a nutrientsensitive complex that signals to the cell growth machinery. Cell 2002, 110:163-175.

39. Jacinto $E$, Loewith $R$, Schmidt A, Lin S, Ruegg MA, Hall A, Hall MN: Mammalian TOR complex 2 controls the actin cytoskeleton and is rapamycin insensitive. Nat Cell Biol 2004, 6:1122-1128.

40. Humar R, Kiefer FN, Berns H, Resink JThérèsa, Battegay EJ: Hypoxia enhances vascular cell proliferation and angiogenesis in vitro via rapamycin (mTOR) -dependent signaling. The FASEB Journal 2002, 16:771-780.

41. Gingras AC, Kennedy SG, O'Leary MA, Sonenberg N, Hay N: 4E-BP1, a repressor of mRNA translation, is phosphorylated and inactivated by the Akt(PKB) signaling pathway. Genes Dev 1998, 12:502-513.

42. Dennis PB, Jaeschke A, Saitoh M, Fowler B, Kozma SC, Thomas G: Mammalian TOR: A Homeostatic ATP Sensor. Science 2001, 294:1102-1105.

43. Lu ZH, Shvartsman MB, Lee AY, Shao JM, Murray MM, Kladney RD, Fan D, Krajewski S, Chiang GG, Mills GB, Arbeit JM: Mammalian Target of Rapamycin Activator RHEB Is Frequently Overexpressed in Human Carcinomas and Is Critical and Sufficient for Skin Epithelial Carcinogenesis. Cancer Research 2010, 70:3287-3298.

44. Memmott RM, Dennis PA: The role of the Akt/mTOR pathway in tobacco carcinogen-induced lung tumorigenesis. Clin Cancer Res 2010, 16:4-10.

45. Tee AR, Manning BD, Roux PP, Cantley LC, Blenis J: Tuberous sclerosis complex gene products, Tuberin and Hamartin, control mTOR signaling by acting as a GTPase-activating protein complex toward Rheb. Curr Biol 2003, 13:1259-1268.

46. Fingar DC, Salama S, Tsou C, Harlow E, Blenis J: Mammalian cell size is controlled by mTOR and its downstream targets S6K1 and 4EBP1/elF4E. Genes Dev 2002, 16:1472-1487.
47. Zhang B, Cao H, Rao GN: 15(S)-Hydroxyeicosatetraenoic Acid Induces Angiogenesis via Activation of PI3K-Akt-mTOR-S6K1 Signaling. Cancer Research 2005, 65:7283-7291.

48. Zeng Z-Z, Yellaturu CR, Neeli I, Rao GN: 5(S)-Hydroxyeicosatetraenoic Acid Stimulates DNA Synthesis in Human Microvascular Endothelial Cells via Activation of Jak/STAT and Phosphatidylinositol 3-Kinase/Akt Signaling, Leading to Induction of Expression of Basic Fibroblast Growth Factor 2. Journal of Biological Chemistry 2002, 277:41213-41219.

49. Jefferies HBJ, Fumagalli S, Dennis PB, Reinhard C, Pearson RB, Thomas G: Rapamycin suppresses 5[prime]TOP mRNA translation through inhibition of p70s6k. EMBO J 1997, 16:3693-3704.

50. De Benedetti A, Graff JR: elF-4E expression and its role in malignancies and metastases. Oncogene 0000, 23:3189-3199.

51. Jones RM, Branda J, Johnston KA, Polymenis M, Gadd M, Rustgi A, Callanan L, Schmidt EV: An essential $E$ box in the promoter of the gene encoding the mRNA cap-binding protein (eukaryotic initiation factor $4 \mathrm{E}$ ) is a target for activation by c-myc. Mol Cell Biol 1996, 16:4754-4764.

52. Rosenwald IB, Lazaris-Karatzas A, Sonenberg N, Schmidt EV: Elevated levels of cyclin D1 protein in response to increased expression of eukaryotic initiation factor 4E. Mol Cell Biol 1993, 13:7358-7363.

53. Kevil CG, De Benedetti A, Payne DK, Coe LL, Laroux FS, Alexander JS: Translational regulation of vascular permeability factor by eukaryotic initiation factor 4E: implications for tumor angiogenesis. Int J Cancer 1996, 65:785-790.

54. Jiang Y, Muschel RJ: Regulation of Matrix Metalloproteinase-9 (MMP-9) by Translational Efficiency in Murine Prostate Carcinoma Cells. Cancer Research 2002, 62:1910-1914.

55. Zhong H, Chiles K, Feldser D, Laughner E, Hanrahan C, Georgescu MM, Simons JW, Semenza GL: Modulation of hypoxia-inducible factor 1alpha expression by the epidermal growth factor/phosphatidylinositol 3kinase/PTEN/AKT/FRAP pathway in human prostate cancer cells: implications for tumor angiogenesis and therapeutics. Cancer Res 2000, 60:1541-1545.

56. Huang S, Shu L, Easton J, Harwood FC, Germain GS, Ichijo H, Houghton PJ: Inhibition of Mammalian Target of Rapamycin Activates Apoptosis Signal-regulating Kinase 1 Signaling by Suppressing Protein Phosphatase 5 Activity. Journal of Biological Chemistry 2004, 279:36490-36496.

57. Liu Q, Thoreen C, Wang J, Sabatini D, Gray NS: mTOR Mediated AntiCancer Drug Discovery. Drug Discov Today Ther Strateg 2009, 6:47-55.

58. Vezina C, Kudelski A, Sehgal SN: Rapamycin (AY-22,989), a new antifungal antibiotic. I. Taxonomy of the producing streptomycete and isolation of the active principle. J Antibiot (Tokyo) 1975, 28:721-726.

59. Brown EJ, Albers MW, Bum Shin T, Ichikawa K, Keith CT, Lane WS, Schreiber SL: A mammalian protein targeted by G1-arresting rapamycinreceptor complex. Nature 1994, 369:756-758.

60. Napoli KL, Taylor PJ: From beach to bedside: history of the development of sirolimus. Ther Drug Monit 2001, 23:559-586.

61. Huang S, Bjornsti MA, Houghton PJ: Rapamycins: mechanism of action and cellular resistance. Cancer Biol Ther 2003, 2:222-232.

62. Boni JP, Hug B, Leister C, Sonnichsen D: Intravenous Temsirolimus in Cancer Patients: Clinical Pharmacology and Dosing Considerations. Seminars in Oncology 2009, 36:S18-S25.

63. Hartford CM, Ratain MJ: Rapamycin: something old, something new, sometimes borrowed and now renewed. Clin Pharmacol Ther 2007, 82:381-388.

64. Crowe A, Bruelisauer A, Duerr L, Guntz P, Lemaire M: Absorption and intestinal metabolism of SDZ-RAD and rapamycin in rats. Drug Metab Dispos 1999, 27:627-632.

65. Kirchner Gl, Meier-Wiedenbach I, Manns MP: Clinical pharmacokinetics of everolimus. Clin Pharmacokinet 2004, 43:83-95.

66. Houghton PJ: Everolimus. Clin Cancer Res 2010, 16:1368-1372.

67. Raymond E, Alexandre J, Faivre S, Vera K, Materman E, Boni J, Leister C, Korth-Bradley J, Hanauske A, Armand JP: Safety and pharmacokinetics of escalated doses of weekly intravenous infusion of $\mathrm{CCl}-779$, a novel mTOR inhibitor, in patients with cancer. J Clin Oncol 2004, 22:2336-2347.

68. Mita MM, Mita AC, Chu QS, Rowinsky EK, Fetterly GJ, Goldston M, Patnaik A, Mathews L, Ricart AD, Mays T, et al: Phase I trial of the novel mammalian target of rapamycin inhibitor deforolimus (AP23573; MK-8669) administered intravenously daily for 5 days every 2 weeks to patients with advanced malignancies. J Clin Oncol 2008, 26:361-367. 
69. Perotti A, Locatelli A, Sessa C, Hess D, Viganó , Capri G, Maur M, Cerny T, Cresta S, Rojo F, et al: Phase IB Study of the mTOR Inhibitor Ridaforolimus With Capecitabine. Journal of Clinical Oncology 2010 28:4554-4561

70. Sorrells DL, Ghali GE, Meschonat C, DeFatta RJ, Black D, Liu L, De Benedetti A, Nathan CO, Li BD: Competitive PCR to detect elF4E gene amplification in head and neck cancer. Head Neck 1999, 21:60-65.

71. Nathan CO, Amirghahari N, Abreo F, Rong X, Caldito G, Jones ML, Zhou H, Smith M, Kimberly D, Glass J: Overexpressed elF4E is functionally active in surgical margins of head and neck cancer patients via activation of the Akt/mammalian target of rapamycin pathway. Clin Cancer Res 2004, 10:5820-5827.

72. Nathan CO, Franklin S, Abreo FW, Nassar R, De Benedetti A, Glass J: Analysis of surgical margins with the molecular marker elF4E: a prognostic factor in patients with head and neck cancer. $J$ Clin Oncol 1999, 17:2909-2914.

73. Nathan CO, Liu L, Li BD, Abreo FW, Nandy I, De Benedetti A: Detection of the proto-oncogene elF4E in surgical margins may predict recurrence in head and neck cancer. Oncogene 1997, 15:579-584.

74. Amornphimoltham P, Sriuranpong V, Patel V, Benavides F, Conti CJ, Sauk J, Sausville EA, Molinolo AA, Gutkind JS: Persistent Activation of the Akt Pathway in Head and Neck Squamous Cell Carcinoma. Clinical Cancer Research 2004, 10:4029-4037.

75. Ekshyyan O, Rong Y, Rong X, Pattani KM, Abreo F, Caldito G, Chang JKS, Ampil F, Glass J, Nathan CO: Comparison of radiosensitizing effects of the mammalian target of rapamycin inhibitor CCl-779 to cisplatin in experimental models of head and neck squamous cell carcinoma. Molecular Cancer Therapeutics 2009, 8:2255-2265.

76. Neshat MS, Mellinghoff IK, Tran C, Stiles B, Thomas G, Petersen R, Frost P, Gibbons JJ, Wu H, Sawyers CL: Enhanced sensitivity of PTEN-deficient tumors to inhibition of FRAP/mTOR. Proc Natl Acad Sci USA 2001, 98:10314-10319.

77. Gera JF, Mellinghoff IK, Shi Y, Rettig MB, Tran C, Hsu J-h, Sawyers CL, Lichtenstein AK: AKT Activity Determines Sensitivity to Mammalian Target of Rapamycin (mTOR) Inhibitors by Regulating Cyclin D1 and cmyc Expression. Journal of Biological Chemistry 2004, 279:2737-2746.

78. Nathan CO, Amirghahari N, Rong X, Giordano T, Sibley D, Nordberg M, Glass J, Agarwal A, Caldito G: Mammalian target of rapamycin inhibitors as possible adjuvant therapy for microscopic residual disease in head and neck squamous cell cancer. Cancer Res 2007, 67:2160-2168.

79. Albert JM, Kim KW, Cao C, Lu B: Targeting the Akt/mammalian target of rapamycin pathway for radiosensitization of breast cancer. Mol Cancer Ther 2006, 5:1183-1189.

80. Clark C, Shah S, Herman-Ferdinandez L, Ekshyyan O, Abreo F, Rong X, McLarty J, Lurie A, Milligan EJ, Nathan C-AO: Teasing out the best molecular marker in the AKT/mTOR pathway in head and neck squamous cell cancer patients. The Laryngoscope 2010, 120:1159-1165.

81. Beuvink I, Boulay A, Fumagalli S, Zilbermann F, Ruetz S, O'Reilly T, Natt F, Hall J, Lane HA, Thomas G: The mTOR Inhibitor RAD001 Sensitizes Tumor Cells to DNA-Damaged Induced Apoptosis through Inhibition of p21 Translation. Cell 2005, 120:747-759.

82. Wangpaichitr M, Wu C, You M, Kuo MT, Feun L, Lampidis T, Savaraj N: Inhibition of mTOR restores cisplatin sensitivity through downregulation of growth and anti-apoptotic proteins. Eur J Pharmacol 2008, 591:124-127.

83. Shinohara ET, Cao C, Niermann K, Mu Y, Zeng F, Hallahan DE, Lu B: Enhanced radiation damage of tumor vasculature by mTOR inhibitors. Oncogene 2005, 24:5414-5422.

84. Manegold PC, Paringer C, Kulka U, Krimmel K, Eichhorn ME, Wilkowski R, Jauch KW, Guba M, Bruns CJ: Antiangiogenic therapy with mammalian target of rapamycin inhibitor RAD001 (Everolimus) increases radiosensitivity in solid cancer. Clin Cancer Res 2008, 14:892-900.

85. Sharafinski ME, Ferris RL, Ferrone S, Grandis JR: Epidermal growth factor receptor targeted therapy of squamous cell carcinoma of the head and neck. Head \& Neck 2010, 32:1412-1421.

86. Jimeno A, Kulesza P, Wheelhouse J, Chan A, Zhang X, Kincaid E, Chen R, Clark DP, Forastiere A, Hidalgo M: Dual EGFR and mTOR targeting in squamous cell carcinoma models, and development of early markers of efficacy. Br J Cancer 2007, 96:952-959.
87. Mackenzie M, Ernst S, Johnson C, Winquist E: A phase I study of temsirolimus and metformin in advanced solid tumours. Investigational New Drugs 2010:1-6.

88. Fury MG, Sherman EJ, Wu N, Haque S, Lisa DM, Carlson D, Pfister DG: Phase I study of everolimus (E) plus low-dose weekly cisplatin (C) for patients with advanced solid tumors. ASCO Meeting Abstracts 2010, 28:e13013.

doi:10.1186/1758-3284-3-22

Cite this article as: Liao et al:: Mammalian target of rapamycin and head and neck squamous cell carcinoma. Head \& Neck Oncology 2011 3:22.

\section{Submit your next manuscript to BioMed Central and take full advantage of:}

- Convenient online submission

- Thorough peer review

- No space constraints or color figure charges

- Immediate publication on acceptance

- Inclusion in PubMed, CAS, Scopus and Google Scholar

- Research which is freely available for redistribution 